\title{
Editorial: Advances in Power-to-X: Processes, Systems, and Deployment
}

\author{
Valerie Eveloy ${ }^{1 *}$, Luis M. Romeo ${ }^{2 *}$, David Parra ${ }^{3 *}$ and Meysam Qadrdan ${ }^{4 *}$ \\ ${ }^{1}$ Department of Mechanical Engineering, Khalifa University, Abu Dhabi, United Arab Emirates, ${ }^{2}$ Department of Mechanical \\ Engineering, University of Zaragoza, Zaragoza, Spain, ${ }^{3}$ Energy Efficiency Group, Institute for Environmental Sciences and Forel \\ Institute, University of Geneva, Genève, Switzerland, ${ }^{4}$ School of Engineering, Cardiff University, Cardiff, United Kingdom
}

Keywords: power-to-X (PtX), power-to-gas (PtG), hydrogen, renewable energy, energy storage, $\mathrm{CO}_{2}$ utilization, electrolysis, methanation

Editorial on the Research Topic

Advances in Power-to-X: Processes, Systems, and Deployment

\section{INTRODUCTION}

\section{OPEN ACCESS}

Edited and reviewed by: Yulong Ding,

University of Birmingham, United Kingdom

*Correspondence: Valerie Eveloy valerie.eveloy@ku.ac.ae Luis M. Romeo luismi@unizar.es

David Parra

david.parra@unige.ch Meysam Qadrdan qadrdanm@cardiff.ac.uk

Specialty section:

This article was submitted to Process and Energy Systems Engineering,

a section of the journa Frontiers in Energy Research

Received: 07 January 2021 Accepted: 05 February 2021

Published: 13 April 2021

Citation:

Eveloy V, Romeo LM, Parra D and Qadrdan M (2021) Editorial: Advances in Power-to-X: Processes, Systems, and Deployment.

Front. Energy Res. 9:650510. doi: 10.3389/fenrg.2021.650510
The storage of surplus electricity is critical to facilitate the large-scale integration of intermittent renewable technologies into energy systems. In this regard, power-to-X ( $\mathrm{PtX})$ technologies are a promising approach to convert and store excess renewable electricity in the form of synthetic fuels, chemicals, and other energy carriers, and to contribute decarbonizing difficult-to-abate sectors such as heavy/long-distance transport and industry (Lund et al., 2015). However, further development of $\mathrm{PtX}$ technologies faces sizeable challenges, including process efficiency limitations, limited availability of affordable (quasi) carbon-neutral carbon dioxide $\left(\mathrm{CO}_{2}\right)$ sources for hydrogenation, and economic aspects (Eveloy, 2019). Such challenges need to be overcome for PtX products to compete economically and in terms of environmental impact with conventional and other alternative energy vectors.

This Frontiers in Energy Research special issue seeks to present recent advancements, and identify challenges and future research needs in the area of PtX. The collection brings together nine research, review, and perspective articles contributed by researchers from academia, government, and industry based in Europe, Australia, and the United States. The topics of these articles are categorized herein into three areas, namely, PtX processes ( 4 articles), systems ( 3 articles), and deployment ( 2 articles).

\section{PTX PROCESSES}

The identification of optimum PtX energy vectors and synthesis pathways for a given application, based on technical and economic considerations, is being extensively pursued (Rego de Vasconcelos and Lavoie, 2019). In terms of energy carriers, hydrogen and methane produced using power-to-gas processes (Götz et al., 2016) have been the most widely investigated to date. Despite the need for additional process steps, equipment, and conversion losses relative to hydrogen, synthetic methane would be more readily supported by existing large-scale gas infrastructure (Lehner et al., 2014) than either pure or blended hydrogen, depending on blending regulations. A sustainable and affordable source of $\mathrm{CO}_{2}$ is however required (Schiebahn et al., 2015). Although synthetic methane could provide a suitable source of $\mathrm{CO}_{2}$, the direct use of biogas in power-to-methane processes without $\mathrm{CO}_{2}$ separation from biogas could reduce process complexity, greenhouse gas (GHG) emissions, and cost, subject to biogas availability. Focusing on the direct use of biogas in power-to-methane 
processes, Calbry-Muzyka and Schildhauer reviewed key challenges associated with the treatment of biogas impurities, and discussed both competing methanation reactor and final upgrading process concepts at a high technology readiness level recently demonstrated at relevant scales. A potential alternative direction to reduce the number of methane synthesis process steps, equipment size, GHG emissions, and cost is based on onestep, in situ solid oxide cell steam and $\mathrm{CO}_{2}$ co-electrolysis. Focusing on such processes, Biswas et al. reviewed recent advancements and challenges in solid oxide cell materials, design, and optimized operating conditions. Ultimately, to effectively and comprehensively evaluate the potential of $\mathrm{PtX}$ technologies to contribute to meeting emission reduction targets, life cycle assessments are required (Sternberg and Bardow, 2015; Wevers et al, 2020). Schreiber et al. presented a life cycle assessment of high-temperature co-electrolysis-based powerto-syngas in the context of German Climate Action Plan 2050 energy scenarios. Generalizing the PtX concept (Bailera et al., 2017), solar-powered semiconductor-based artificial photosynthesis is another category of processes having the potential to reduce the complexity and increase the efficiency of water and/or $\mathrm{CO}_{2}$ conversion processes to produce hydrogen, methane, syngas, liquid fuels (e.g., methanol), and chemicals (e.g., ammonia and formic acid). Mi and Sick provided a perspective on recent developments and techno-economic prospects of three major such process paths, namely, photocatalytic, photoelectrochemical, and photovoltaic-electrolysis, in terms of efficiency, stability and cost, and candidate promising semiconductor light absorber materials and catalysts.

\section{PTX SYSTEMS}

The design, evaluation, and optimization of $\mathrm{PtX}$ systems involve efforts at the prototype to plant or facility level, using a combination of experimentation and modeling. At the $\mathrm{PtX}$ prototype element level, Barton et al. experimentally characterized and modeled the dynamic performance of a novel nickel-iron battery-electrolyzer or "battolyser" prototype cell intended for both short-term (as a battery) and long-term energy storage (as an electrolyzer), either in remote mini-grid or national energy system applications. At the prototype level, bioelectrochemical power-to-methane reactors may offer a low-energy, single-step methanation route (i.e., without the need for preliminary hydrogen production) with simultaneous wastewater treatment. Molognoni et al. experimentally investigated the long-term performance of such a prototype reactor integrating $\mathrm{CO}_{2}$ capture in wastewater via membrane contactors. At the facility level, combined cycle power plants in future renewable-dominated energy systems are expected to mainly serve as flexible regulating generators, the efficiency and economics of which could be adversely affected by low capacity/load utilization (Song et al., 2020). Bailera et al. investigated the use of power-to-methane under a range of combined cycle power plant start-up scenarios to virtually reduce plant minimum complaint load, hence augmenting electricity revenues and reducing specific $\mathrm{CO}_{2}$ emissions.

\section{PTX DEPLOYMENT}

PtX techno-economic deployment studies and demonstration projects are critical to identify optimum plant configurations and their integration into energy systems, including supporting appropriate market structures and regulatory frameworks (Bailera et al., 2017; Eveloy and Gebreegziabher, 2018). The strategic role, cost, and value creation of PtX applications require to be carefully assessed to enable effective deployment strategies (Parra et al., 2019). Wulf et al. reviewed $220 \mathrm{PtX}$ demonstration projects in Europe, in terms of commissioning time, location, capacity, electricity/ $/ \mathrm{CO}_{2}$ sources, electrolysis, and hydrogen post-processing technologies, and targeted PtX product applications, leading to recommendations on future PtX project strategies. Focusing on the management of wind generation in the 2030 Great Britain energy system, Ameli et al. evaluated an integrated, optimized approach to operate gas and electricity systems assisted with power-to-gas and other flexibility technologies, to reduce annual operating cost and GHG emissions, and improve the security of gas supply.

\section{OUTLOOK}

This Research Topic collection advances our understanding on the emerging and important role that PtX technologies are likely to play in future energy systems, as well as on challenges and future research needs in these areas. The further development of PtX technologies will ultimately depend on the level of decarbonization and renewable energy penetration in energy systems. Diversity in processes, products, and applications is essential to optimize the use of local resources in meeting local, national, and global energy/feedstock demands, while minimizing deployment risks. The Guest Editors hope that the readers of this collection will find the research presented informative and useful in pursuing their own research and development activities in the areas of PtX and sustainable energy systems.

\section{AUTHOR CONTRIBUTIONS}

VE wrote the initial editorial draft. LM, DP, and MQ critically reviewed the initial editorial draft.

\section{ACKNOWLEDGMENTS}

The guest editors express their gratitude to Frontiers in Energy Research editor in chief, section editors, and associate editor for their support and constructive feedback. The guest editors also thank all reviewers for their time and highly appreciated contributions in peer reviewing the authors' work. The guest editors especially thank the Review and Editorial Teams of Frontiers in Energy Research for their excellent support. 


\section{REFERENCES}

Bailera, M., Lisbona, P., Romeo, L. M., and Espatolero, S. (2017). Power to gas projects review: lab, pilot and demo plants for storing renewable energy and $\mathrm{CO}_{2}$. Renew. Sustain. Energ. Rev. 69, 292-312. doi:10.1016/j.rser.2016.11.130

Eveloy, V., and Gebreegziabher, T. (2018). A review of projected power-to-gas deployment scenarios. Energies 11 (7), 1824. doi:10.3390/en11071824

Eveloy, V. (2019). Hybridization of solid oxide electrolysis-based power-tomethane with oxyfuel combustion and carbon dioxide utilization for energy storage. Renew. Sust. Energ. Rev. 108, 550-571. doi:10.1016/j.rser.2019.02.027

Götz, M., Lefebvre, J., Mörs, F., McDaniel Koch, A., Graf, F., Bajohr, S, Reimert, R, and Kolb, T (2016). Renewable power-to-gas: a technological and economic review. Renew. Energ. 85, 1371-1390. doi:10.1016/j.renene.2015.07.066

Lehner, M., Tichler, R., Steinmüller, H., and Koppe, M. (2014). Power-to-Gas: technology and business models, Vol. 39. Berlin, Germany: Springer. doi:10.1007/978-3-319-03995-4

Lund, P. D., Lindgren, J., Mikkola, J., and Salpakari, J. (2015). Review of energy system flexibility measures to enable high levels of variable renewable electricity. Renew. Sustain. Energ. Rev. 45, 785-807. doi:10.1016/j.rser.2015.01.057

Parra, D., Valverde, L., Javier Pino, F., and Patel, M. K. (2019). A review on the role, cost and value of hydrogen energy systems for deep decarbonisation. Renew. Sustain. Energ. Rev. 101, 279-294. doi:10.1016/j.rser.2018.11.010

Rego de Vasconcelos, B., and Lavoie, J.-M. (2019). Recent advances in power-to-X technology for the production of fuels and chemicals. Front. Chem. 7, 392. doi:10.3389/fchem.2019.00392
Schiebahn, S., Grube, T., Robinius, M., Tietze, V., Kumar, B., and Stolten, D. (2015) Power to gas: technological overview, systems analysis and economic assessment for a case study in Germany. Int. J. Hydrog. Energ. 40, 4285-4294. doi:10.1016/j.ijhydene.2015.01.123

Song, X., Lin, C., Zhang, R., Jiang, T., and Chen, H. (2020). Two-stage stochastic scheduling of integrated electricity and natural gas systems considering ramping costs with power-to-gas storage and wind power. Front. Energy Res. 8:596774. doi:10.3389/fenrg.2020.596774

Sternberg, A., and Bardow, A. (2015). Power-to-What? - environmental assessment of energy storage systems. Energy Environ. Sci. 8, 389-400. doi:10.1039/c4ee03051f

Wevers, JB., Shen, L., and van der Spek, M. (2020). What Does It Take to Go Net-Zero$\mathrm{CO}_{2}$ ? A life cycle assessment on long-term storage of intermittent renewables with chemical energy carriers. Front. Energy Res. 8:104. doi:10.3389/fenrg.2020.00104

Conflict of Interest: The authors declare that the research was conducted in the absence of any commercial or financial relationships that could be construed as a potential conflict of interest.

Copyright (c) 2021 Eveloy, Romeo, Parra and Qadrdan. This is an open-access article distributed under the terms of the Creative Commons Attribution License (CC BY) The use, distribution or reproduction in other forums is permitted, provided the original author(s) and the copyright owner(s) are credited and that the original publication in this journal is cited, in accordance with accepted academic practice. No use, distribution or reproduction is permitted which does not comply with these terms. 